\title{
Impact of warming climate on water management for the Ariège river basin (France)
}

\author{
F. Hendrickx ${ }^{1}$ and E. Sauquet ${ }^{2}$ \\ EDF Research and Development, LNHE, 6 quai Watier, F-78401 Chatou, France \\ frederic.hendrickx@edf.fr
}

Irstea, UR HHLY, 5 rue de la Doua - CS70077, F-69626 Villeurbanne cedex, France eric.sauquet@irstea.fr

Received 25 January 2012; accepted 20 December 2012; open for discussion until 1 January 2014

Citation Hendrickx, F. and Sauquet, E., 2013. Impact of warming climate on water management for the Ariège river basin (France). Hydrological Sciences Journal, 58 (4), 1-17.

\begin{abstract}
The French national project IMAGINE2030 aims to assess future water availability in the Garonne River basin (southwest France) by taking account of changes in both climate and water management in the 2030s. Within this project, two mountainous drainage basins located in the Pyrenees were examined to assess the specific impact of climate change on reservoir management. The Salat River basin at Roquefort, is considered as a proxy (representative of a natural basin), whereas the Ariège River at Foix is influenced by hydropower production in winter and by water releases to sustain low flows in summer. The Cequeau rainfall-runoff model, combined with a simplified model of reservoir management operations, was calibrated on present-day conditions and forced with climate projections derived from the IPCC AR4 report. The results show that a warming climate over the basins induces a decrease in mean annual runoff, a shift to earlier snow melting in mountainous areas and more severe low-flow conditions. The simulations show a decrease in electricity generation. Under two water management scenarios (one "business-as-usual" and the other incorporating an increased downstream water demand in compliance with requirements for increased minimum flow), simulations for the Ariège River basin suggest an earlier filling of the reservoir is necessary in winter to anticipate the increased release from reservoirs in summer to support minimum flow farther downstream..
\end{abstract}

Key words water management, climate change, France, hydropower, low flow, Garonne

\section{Impact du changement climatique sur la gestion de l'eau dans le bassin de l'Ariège (France)}

Résumé Le projet national français IMAGINE2030 examine l'évolution de la ressource en eau et ses conséquences sur la gestion dans le bassin de la Garonne à l'horizon 2030. Deux bassins de montagne ont été particulièrement étudiés pour mesurer l'impact du changement climatique sur la gestion des ouvrages hydrauliques. Le Salat à Roquefort est un bassin de montagne, considéré comme témoin naturel, tandis que l'Ariège à Foix est influencée par la production hydroélectrique en hiver et le soutien d'étiage en été. Le modèle hydrologique Cequeau, combiné à un module simplifié représentant les manoeuvres aux ouvrages, a été calé sur des données représentatives de la situation actuelle et alimenté par des projections climatiques établies sur la base de l'exercice AR4 du GIEC (IPCC). Les résultats montrent des apports annuels en baisse, une fonte de la neige plus précoce et une sévérité accrue des étiages en réponse à des températures plus élevées dès 2030 et plus spécifiquement une diminution de la production électrique sur le bassin de l'Ariège à Foix. En considérant deux scénarios de gestion, le premier «business as usual » et le second intégrant une demande aval accrue au travers de l'augmentation du débit minimal à respecter, un remplissage avancé des réservoirs sur l'Ariège est nécessaire pendant l'hiver pour anticiper une contribution plus forte de ces réservoirs au soutien d'étiage estival en aval.

Mots clefs gestion de l'eau, changement climatique, France, hydro-électricité, étiage, Garonne 
Located in southwest France, the Garonne River basin (approx. area: $65000 \mathrm{~km}^{2}$ ) is one of the five major French river basins. This basin is surrounded by mountains (the Pyrenees to the south and the Massif Central to the east) and by a wide alluvial plain on the northern side. River flow regimes observed within the basin (Sauquet et al. 2008) are influenced by different climates ranging from mountainous conditions in the upper part of the basin to continental rainy conditions in the lowlands. In addition river flows are greatly altered by water management (abstraction, reservoirs, derivations, etc.).

The severe low flows recently observed during 2003, 2005 and 2006 have indicated the vulnerability of the systems for allocating water between the main users of this resource, whose interests may conflict. Competition within and between sectors is increasing, and water resources are already under heavy pressure. With economic development, the need and demand for water will probably undergo changes. In parallel, the European Water Framework Directive and the French policy on water management seek to ensure compliance with good ecological status before 2015 , restricting water availability for water users.

Several studies have already investigated the impact of climate change on water resources in southwest France. On the basis of seven climate projections from seven different global climate models (GCMs) running with $\mathrm{CO} 2$ concentrations reaching near twice present-day concentrations by 2050, Caballero et al. (2007) suggest a decline in low flow by $13 \% \pm 11 \%$ for the Garonne River at Lamagistère from the present to the mid-21st century. Discharges in spring and autumn are also reduced, whereas discharges in winter are projected to increase for most of the climate projections and the 16 river basins under study. Impacts on low flows are moderate, since the effect of a warmer climate and drier summers penalising water resources is partially compensated by wetter winters. The Safran-Isba-Modcou (SIM) hydrometeorological modelling system was applied to simulate future discharge response to a perturbed climate. The SIM model was recently re-used by Boé et al. (2009) to examine the impact of future climate on the hydrological cycle of the main French river basins, and to assess uncertainties linked to climate models and downscaling techniques. The forcing data were composed of a set of 17 downscaled climate scenarios. The Garonne River basin was found to be the most severely impacted basin, with declining precipitation and increasing temperature for all the seasons resulting in a significant reduction of low flows by the 2050s (e.g. the relative change in mean summer discharge for the Garonne River basin at Lamagistère is projected to lie between $-22 \%$ and $-42 \%$ ). Tisseuil et al. (2010) developed a new downscaling approach to derive river flow characteristics directly from GCM outputs, applying it to southwestern France. The results show a pronounced decrease in mean summer discharge of basins with rainfall-fed river flow regimes, including the Garonne River basin at Tonneins $\left(51500 \mathrm{~km}^{2}\right)$ close to its outlet..

All these recent studies suggest a considerable modification of water availability for the future, with a clear tendency towards more severe low flows. However, none of these studies has explicitly taken into account reservoir operations within the basin, or has questioned the sustainability of present-day water management. The present study is intended to fill these gaps, and also forms part of a French national project IMAGINE2030: "ClImate and water MAnaGement: uncertainties on water resources for the Garonne rivEr basin in 2030". This project (Sauquet et al. 2009) involves: the National Research Institute of Science and Technology for Environment and Agriculture (Irstea, formerly Cemagref); Electricité de France, one of the major water stakeholders as electricity producer; and the Adour 
Garonne Water Agency. Through an integrated study, IMAGINE2030 aims to assess both current and future risks of water shortage in the 2030s, while taking into account changes in climate and human activities. The study area encompasses nine sub-basins of the Garonne River basin upstream from Lamagistère (32 $\left.500 \mathrm{~km}^{2}\right)$ (Fig. 1).

This paper focuses on the most innovative aspect of the project. We develop here the first model for simulating hydropower reservoir management in France, which allows us to assess the impact of climate change on river flow regime, applying it to a case study in the Pyrenees: the Ariège River at Foix $\left(1340 \mathrm{~km}^{2}\right)$. This sub-basin is located in the mountainous part of the Garonne River basin. The river flow regime is influenced by a series of high elevation reservoirs primarily dedicated to producing hydro-electric power. Due to their high elevation, this series of reservoirs mostly relies on snowmelt. Moreover, there are water transfers from one year to another between the Ebro River basin, located on the southern side of the Pyrenees in Spain, and the headwaters of the Ariège River basin in France. For comparison, we also show the results obtained for a neighbouring basin, i.e. the Salat River basin at Roquefort, with a similar catchment drainage area $\left(1570 \mathrm{~km}^{2}\right)$ but not significantly affected by human activities.

In the present study, we first describe the data used. The rainfall-runoff model and the simplified model of hydropower reservoir management are then outlined, along with the results of their application to the case study discussed in the two first sections. The following section is dedicated to the methodology of constructing transient daily climate projections. We then show the projected changes, including the effects due to both reservoir operations and climate change. We also discuss the main sources of uncertainty affecting projections, before drawing some general conclusions.

\section{DATA}

Historical climatological data are extracted from the 8-km-resolution atmospheric reanalysis over France performed with the Safran gauge-based system (Quintana-Seguí et al. 2008, Vidal et al. 2010). The variables of interest for this study are daily mean temperature and daily mean total precipitation.

Observed daily discharge time series for the Salat River at Roquefort and for the Ariège River at Foix are available in the French database HYDRO (http://www.hydro.eaufrance.fr/) for the periods 1970-2006 and 1970-2005, respectively. Inflows for the Ariège River at Foix were naturalized over the 19902004 sub-period using historical records of reservoir level variations, as well as released discharges for hydropower production and overflows for all dams located in the headwaters. The curve resulting from this correction is shown in comparison with the mean annual hydrographs for the Ariège River (middle of the right panel in Fig. 1): during spring and early summer, reservoirs store inflows naturally produced by snowmelt; in winter, stored water is released to meet unscheduled high peak demands for energy and, in summer, reservoirs give water back to meet multipurpose needs such as agriculture, recreation, drinking water or ecological services. Between 25\% and $33 \%$ of the mean annual flow observed at Foix is actually involved in water management operations in the main head reservoirs. The natural river flow regime of the two basins is predominantly affected by snowmelt processes. Both basins have a mean annual runoff of about $40 \mathrm{~m}^{3} \mathrm{~s}^{-1}$.

For this study, a total of 34 climate projections from the Intergovernmental Panel on Climate Change Fourth Assessment Report (AR4) (IPCC 2007) were used: 
13 GCMs under the A1B SRES emissions scenarios, 10 GCMs under the A2 SRES emissions scenarios and 11 GCMs under the B1 SRES emissions scenarios. The climate simulations were obtained from the IPCC Data Distribution Center (http://www.ipcc-data.org).

\section{THE CEQUEAU RAINFALL-RUNOFF MODEL}

The distributed rainfall-runoff model known as Cequeau (Charbonneau et al. 1977) is adopted here for predicting natural daily discharge. This conceptual model has already been successfully applied to simulate observed river flows under various climatic conditions (e.g. Ayadi and Bergaoui 1998, Hendrickx 2001, Manoha et al. 2008).

The Cequeau model comprises a runoff production function that generates runoff from precipitation (rain or snow) at each cell based on a series of interconnected conceptual reservoirs. The transfer function is represented by a reservoir cascade that transforms direct and subsurface runoff (provided by the production function) into surface runoff in the drainage network.

The Thornthwaite formulation (Thornthwaite 1948) is used to estimate daily potential evapotranspiration. Snow accumulation is simulated within each grid cell at daily time steps using precipitation and air temperature data. The snowmelt equation is based on the temperature index degree-day method developed by the US Army Corps of Engineers (USACE 1956). The Cequeau model estimates the components of the water balance, including snowpack melt and accumulation, at each time step for each cell. The ability to simulate snow-related processes-which is fundamental to correctly reproduce runoff in mountainous areas-is one of the reasons for selecting the Cequeau model for this impact study.

Inputs correspond to the daily temperature and rainfall data provided by the Safran re-analysis at each point of the 8-km grid. The Nash-Sutcliffe efficiency criterion, NSE (Nash and Sutcliffe 1970), calculated on the natural and simulated daily discharge series, is used as a goodness-of-fit measure. A split-sample procedure (Klemeš 1986) is carried out to calibrate Cequeau against naturalized or natural flow by evaluating parameters in turn for two sub-periods (with a preceding 1-year model spin-up period). Results for the Roquefort River basin show small differences in performance over the two sub-periods; e.g. the NSE criterion is 0.86 over the period 1971-1988 in calibration and 0.85 for the period 1989-2006 in validation, despite contrasted climate conditions for calibration and validation (change in mean annual temperature of $1{ }^{\circ} \mathrm{C}$ and in total annual precipitation of $13 \%$ ). Conversely, performance in validation for the Ariège River basin is very sensitive to the choice of calibration period. This could be due to the short period of available inflows and to the uncertainties related to the naturalization procedure. Considering the entire period of record, the NSE criterion is 0.79 and 0.86 for the Ariège and Salat River basins, respectively. Figure 2 illustrates the ability of Cequeau to reproduce three pth percentiles $\mathrm{Q}_{\mathrm{d}} p$ derived from the empirical distribution of daily discharges for each Julian day, associated with exceedence probabilities of $p=5 \%, 50 \%$ and $95 \%$, respectively. The marked variability of observed $Q_{d} 95$ values for the Ariège River basin compared to the Salat River basin is clearly an artefact of the naturalization procedure. Overall, the main aspects of seasonality within the year are satisfactorily captured. The Cequeau rainfall-runoff model demonstrates its ability to reproduce the basic characteristics of river flow regimes and, implicitly, the dominant hydrological processes_-related to snowmelt—in the two Pyrenean case studies. 


\section{SIMPLIFIED MODEL OF HYDROPOWER RESERVOIR MANAGEMENT}

Numerous works on the impact of climate change on water resources can be found in the literature. However, few studies have examined potential changes in hydropower production (Minville et al. 2010). Schaefli et al. (2007) and Finger et al. (2012) simulated dam operations and power generation of reservoirs located in the Swiss Alps. There are no well-defined management rules, and energy demand is not explicitly included in these applications. Both studies conclude that climate change will lead to decrease of glacier extent, as well as of hydropower production. Other published works used simplified representations of current dam operations. The ColSim reservoir operation model developed by Hamlet and Lettenmaier (1999) was later used by Payne et al. (2004), Markoff and Cullen (2008) and Hamlet et al. (2010) to simulate hydropower production at different time slices in the Pacific Northwest and Washington State, USA. Christensen et al. (2004) and, more recently, Christensen and Lettenmaier (2007) ran a simplified version of the Colorado River Simulation System (USDOI 1985), forced by monthly inflows simulated by the Variable Infiltration Capacity (VIC) macroscale hydrological model. The CVmod model was developed by Van Rheenen et al. (2004) to simulate water storage in the main reservoirs located within the Sacramento-San Joaquin River basin (California) at a monthly time step. Fortin et al. (2007) also developed a model that represents operating rules for two multipurpose reservoirs (hydropower generation, water supply, flood control in spring, ecological targets in spring, recreational uses in summer and autumn) in Québec, Canada. Payne et al. (2004), Christensen et al. (2004), Van Rheenen et al. (2004) and Fortin et al. (2007) have tested different technical measures, including timing shifts in reservoir refill and changes in authorized maximum water levels, for mitigating the negative impacts of climate change. Markoff and Cullen (2008) used results from ColSimand also from another model, Genesys (NPCC 2003), on a reduced set of hydrological projections to derive simple empirical formulas linking changes in energy production and changes in seasonal meteorological forcing; they found the hydropower systems to be more sensitive to change in precipitation than to temperature modification. Hamlet et al. (2010) demonstrated that changes in energy production are positively correlated with changes in river flow regime, i.e. seasonal trends in discharge and in energy production share the same sign. Under the assumption of increase of future energy demand in parallel with population growth and the development of air-conditioning, greater difficulties are expected in adapting both water and energy management in summer in the next decades. More sophisticated models based on maximization of benefits have been developed by Turgeon (2005) and applied later by Minville et al. $(2009,2010)$ on the Peribonka River (Québec), by Madani and Lund (2009) and by Vicuña et al. (2008), both with applications in California (Madani and Lund 2010, Vicuña et al. 2011). These two study areas in Canada and the USA may experience a shift in timing of natural high flows and a reduction in snow contribution due to temperature increase. Minville et al. (2009, 2010) and Madani and Lund (2010) pointed out a possible rise in unproductive spills that may result in losses in reservoir efficiency. Three scenarios for hydrology corresponding to three different climate change scenarios were run through the monthly-based optimization model EBHOM (Madani and Lund 2009). The results show that, under the dry and warm climate, profits are expected to reduce with respect to the baseline simulation for the two high-elevation systems studied in California. The study by Vicuña et al. (2011) suggests a decrease in revenue as a consequence of the reduction in annual inflows. 
These findings and conclusions demonstrate the diversity of the impact of climate change on hydropower using projections for climate, water use and electricity demand (e.g. attributable to air conditioning use, residential heating, etc.). The approach proposed within the IMAGINE2030 project is similar to that of the models applied in these previous works. A water demand prioritization model coupled with the Cequeau rainfall-runoff model was developed to account for the links between water demand, local hydropower production and the French electricity grid.

One of the particularities of the French electricity production system is that most of the energy demand (approx. 80\%) is supplied by nuclear power plants. The baseline capacity for nuclear electricity production has to be supplemented by hydropower to ensure matching between supply and demand in real time. This flexible energy source is mainly used to manage peak demands for heating in winter during cold weather conditions and, occasionally, to a lesser extent, at other times. Electricity demand is highly dependent on air temperature, with a different sensitivity between winter and summer: energy demand is increased by $+1700 \mathrm{MW}$ per $-1^{\circ} \mathrm{C}$ in winter and by $+400 \mathrm{MW}$ per $+1^{\circ} \mathrm{C}$ during hot summers over France. In addition to producing electricity, reservoirs located in the Ariège drainage basin tend to moderate the extremes of low flow (water is released to increase downstream discharges).

The relationships between reservoir operations in the Pyrenees within the context of the French electricity grid are too complicated to model in detail, as we do not have the necessary information about the individual plants of the hydropower system. Instead, we adopt a simplified modelling approach, which takes into account only the main drivers of water storage and release at the basin scale. The model was developed bearing in mind that input data should be easily available to facilitate studies on the impact of climate change. The main characteristics of the model are:

(a) to manage reservoir operations, which consists essentially of addressing the issue of whether water should be released in the short term, or stored for use at a later stage;

(b) to ignore electricity prices and only be driven by meteorological and hydrological conditions;

(c) to be based on dynamic programming very similar to the operational tools used by Electricité De France for water management, an approach that involves optimizing the quantity of released water, $R$, that maximizes a benefit function, $B$, using the following recursive equation established for a given time step, $t$ :

$B_{t}\left(S_{t}\right)=\max _{R}\left(P_{t} \cdot R_{t}+B_{t+1}\left(S_{t}-R_{t}+I_{t}\right)\right)$

where $S$ is the stored volume, $P$ the daily benefit derived from a release, $R$ the daily released volume, and $I$ the daily inflow volume. The benefit function $B$ expresses the economic value of storage $S$ at a time step $t$, given the initial and final target states of the system. Equation (1) thus allows us to determine the optimal trajectory of the stored volume over the period considered.

For this application,

- In operational mode, reservoir operations are adjusted at least three times a day based on updated information, including weather forecasts and the availability of energy facilities. The short time step of the decision-making process cannot be achieved easily. A daily time step was finally used for calculation. This may result in a slightly less-than-optimal simulation of water allocation.

- The marginal cost of electricity is estimated using a simple empirical formula. Different tests led to the following expression for the benefit of daily release, $P$ :

$P_{t}=\max \left(0 ; 15-T_{t}^{\text {France }}\right)$ 
where $T^{\text {France }}\left({ }^{\circ} \mathrm{C}\right)$ is the air temperature in France.

- The Cequeau rainfall-runoff model provides information on the input of water, $I$, into a reservoir at a daily time step.

- A regulatory constraint stipulating a minimum daily discharge of $8 \mathrm{~m}^{3} \mathrm{~s}^{-1}$ at Foix is added to satisfy downstream multi-purpose uses in summer, such as irrigation systems, navigation, drinking water supply, ecological services (Cavitte and Moor 2004). Other constraints related to the French water laws of 1992 and 2006 exist, but they are less restrictive for water management than the obligation to guarantee at least $8 \mathrm{~m}^{3} \mathrm{~s}^{-1}$ at Foix.

- All the reservoirs of the Ariège River basin are aggregated into a single reservoir.

- The model is run deterministically with a known future, i.e. assuming perfect foresight of both future natural inflows, $I$ and air temperature in France, $T^{\text {France }}$. The results obtained should be interpreted as the optimal path for integrated water management, especially in the context of a perturbed climate.

Figure 3(a) compares daily observed and simulated discharges, based on the same statistics as displayed in Fig. 2. The results demonstrate the relatively good performance of this simplified model and its ability to represent the seasonal influence of reservoir management on the natural hydrological river flow regime. The NSE criterion computed on observed and simulated daily regulated discharges reaches 0.71 for the period 1972-2005. This performance is consistent with the degree of refinement in the representation of reservoir management. In addition to daily discharge statistics, Fig. 3(b) also shows the stored water volume. While no observed data are available for comparison, the obtained trajectories are nevertheless consistent with the total reservoir storage capacity of $200 \mathrm{hm}^{3}$ and with the known reservoir operations; storage is simulated between day 106 (15 April) and day 301 (26 October), including the major filling period during snowmelt in spring, whereas release is observed at other times.

\section{RESAMPLING TECHNIQUE TO DERIVE PERTURBED METEOROLOGICAL SCENARIOS}

Only monthly climatic time series (Vidal and Sauquet 2010) were available at the beginning of the IMAGINE2030 project. This data set consists of 34 monthly gridded local projections obtained by the Bias-corrected Local Mapping (BLM) procedure (Vidal and Wade 2008) performed on 34 IPCC AR4 runs. The application to the Garonne River basin makes use of observed data and the grid of the Safran meteorological archive. Results are given as monthly projections of 8-km gridded precipitation and air temperature over the study area for each GCM. Figure 4 shows the transient moving-average temperature and precipitation throughout the 1980-2030 period. Table 1 summarizes the results for specific periods, including the historic baseline taken throughout as the climate averaged over the period 1970-1989. A comparison with statistics derived from the Safran re-analysis demonstrates that current conditions are reasonably well reproduced by bias-corrected GCMs. On a seasonal basis, there is good agreement between projections in temperature, with increases ranging on average from $+1^{\circ} \mathrm{C}$ to $+2^{\circ} \mathrm{C}$ for the $2021-2040$ period. The data presented in Fig. 4 and Table 1 also suggest that potential changes in future precipitation are more uncertain. Dispersion in the projections globally increases with greater distance into the future. Dispersion between projected precipitations is high, especially in winter. The magnitudes of the changes in precipitation are weak, except in summer, for which the most notable changes are projected, i.e. a maximum 
decrease of $33 \%$ in precipitation together with an increase in temperature by up to $+4^{\circ} \mathrm{C}$ over the $34 \mathrm{GCMs}$. Using the average of the $34 \mathrm{AR} 4$ climate projections, the Garonne River basin will experience a warmer and drier climate for the 2021-2040 period: $75 \%$ of the models predict a decline in annual precipitation, and all the models point to an upward trend in mean annual temperature.

Daily data were required as model inputs. A simple way to overcome this problem is to apply the delta-change method, certainly the simplest and most frequently-used technique, despite its well-known limitations (e.g. Diaz-Nieto and Wilby 2005). Our wish was to develop projections based on the most reliable information provided by the GCMs (projections of air temperature are more consistent than projections of precipitation), while ensuring realistic values in meteorological forcings. The approach applied uses non-parametric resampling partly conditioned by the available monthly GCM outputs.

The chosen algorithm is the modified k-nearest neighbour (KNN) approach (Lall and Sharma 1996), which provides stochastically a consistent set of multivariable time series sampled from observed past situations. To generate the vector of climatic variables for day $t+1$, we first make use of a meteorological historical archive to select a set of $k$ days with characteristics analogous to those simulated for day $t$. The potential candidates for $k$ analogous situations are all days included within the $N$ time windows of days that are centred around the target ordinal date corresponding to $t$ of all the $N$ available years. Days are ranked according to the Mahalanobis distance measuring their similarity to day $t$. Finally, one of the $k$ closest neighbours is randomly selected and the observed values for the day following that neighbour are considered as the values for day $t+1$. Lall and Sharma (1996) suggest giving more weight to closer neighbours in the probability distribution. Each of the analogous days $d(i), i=1, \ldots, k$ ranked according to its degree of similarity with day $t$ has the following probability of being randomly selected:

$$
\operatorname{Prob}(t=d(i))=1 / i / \sum_{j=1}^{k} 1 / j
$$

Here, we adopt the procedure suggested by Yates et al. (2003) and Sharif and Burn (2006) to develop an ensemble of precipitation and temperature time series conditioned according to trends identified in climate projections. The KNN algorithm is modified so that some years - corresponding to certain meteorological situations - are favoured rather than others. A list is first established of $N$ years, which are sorted with respect to prescribed additional criteria (e.g. from the driest to the wettest period for all years). A $N$-dimension vector $\left(x_{i}, i=1, \ldots, N\right)$ is randomly generated:

$$
x_{i}=\operatorname{INT}\left[N \times\left(1-r^{s}\right)\right]+1
$$

where $r \sim U(0,1)$ is a random number and $\mathrm{S}$ is a positive shape parameter to be fixed. Lastly, the analogous day among the k-nearest neighbours with associated rank $j$ in the sorted list of records is repeated as many times $\left(\mathrm{nd}_{j}, j=1, \ldots, N\right)$ as $\mathrm{j}$ appears in the randomly generated vector $\left(x_{i}, i=1, \ldots, N\right)$. No bias is simulated when $S=1$. A bias toward the selection of days with high rank is observed when $S>1$. Conversely, a bias toward the selection of days with low rank is observed when $S<1$. The potential candidates for the $k$ analogous situations are thus all the days included within the $N$ time windows repeated $\mathrm{nd}_{j}$ times according to the rank $j$ of the year of record.

Adaptations have been required to develop transient climate projections. We first consider that the effect of climate change has become apparent since a specific year ( year $_{\text {start }}$ ) and, second, that these changes are modelled by the parameter $S$, which is assumed to be a function of time as follows: 


$$
\begin{aligned}
& S(\text { season, year })=1 \\
& \left.S(\text { season, year })=1+\left(0.5+r_{1}\right) S_{0} \text { (season }\right) f(\text { year }) \\
& \text { if year } \leq \text { year }_{\text {start }} \\
& \text { else }
\end{aligned}
$$

with $r_{1} \sim U(0,1)$. The term $\left(0.5+r_{1}\right)$ is introduced to represent the spread in GCMprojected changes. Each KNN scenario differs from the others by the random value attributed to $r_{1}$. The function $\mathrm{f}$ and the four parameters $S_{0}$ account for the long-term trend specific for each season. Equation (6) is the only novelty introduced in the KNN algorithm published by Yates et al. (2003) and Sharif and Burn (2006).

A set of twenty 70 -year daily projections, conditioned by these 34 downscaled IPCC AR4 model simulations, has been developed by applying the modified KNN approach. For the application:

- The decision was taken to bias the KNN algorithm with respect to the most robust trend, i.e. to constrain the biasing by the evolution in average air temperature. The four parameters $S_{0}(\mathrm{DJF}), S_{0}(\mathrm{MAM}), S_{0}(\mathrm{JJA})$ and $S_{0}(\mathrm{SON})$ are calibrated in such a way that the seasonal trends computed on the ensemble medians of temperature fit with trends identified on the downscaled AR4 projections for the Garonne River basin at Lamagistère. By imposing this constraint over the whole basin, consistency is ensured between the climate projections obtained for the sub-basins studied in the project IMAGINE2030.

- Daily precipitation and air temperature data were generated for each 8-km grid cell within the Garonne River basin upstream from Lamagistère.

- Each of the $N$ available years was divided into decades: $\left(\operatorname{dec}_{i, j}, i=1, \ldots, 36, j=\right.$ $1, \ldots, N)$. For fixed $i$; $\left(\operatorname{dec}_{i, j}, j=1, \ldots, N\right)$ values were ranked from the coldest rank 1) to the warmest (rank $N$ ). Each of the k-nearest neighbours observed in decade $\operatorname{dec}_{i, j}$ with associated rank $m$ is repeated $\mathrm{nd}_{m}$ times in the final list of candidate days.

- year $_{\text {start }}$ is fixed at 1990 .

- $f$ is given by a simple linear model:

$$
f(\text { year })=(\text { year }-1990) /(2040-1990)
$$

The final results are displayed in Fig. 4 and Table 1 . The parameters $S_{0}(\mathrm{DJF})$, $S_{0}$ (MAM), $S_{0}$ (JJA) and $S_{0}(\mathrm{SON})$ are fixed at $1,1.25,4.5$ and 2 , respectively. As expected, $S_{0}(\mathrm{JJA})$ is the highest value, since most changes in temperature are expected in summer and $S_{0}(\mathrm{DJF})$ is taken as equal to 1 , because no strong change is projected for this season. Figure 5 displays the number of times $\left(\mathrm{nd}_{j}, j=1, \ldots, N\right)$ each day is repeated according to its rank $j$ in the list of potential candidates for the k-nearest neighbours in 2040 for each seasonal shape parameter $S_{0}$. The time series of daily temperature in France $\left(T^{\text {France }}\right)$ associated with each KNN scenario is composed of observed values for the sampled days.

The results reported in Fig. 4 and Table 1 show an acceptable fit between changes in median temperature derived from the BLM climate projections and those obtained applying the KNN algorithm. The dispersion characterized by the interdecile range is slightly less well reproduced, with a tendency towards a systematic underestimation of the dispersion.

It is also noteworthy that the bias imposed on temperature leads to scenarios that are on the whole drier and less dispersed than those obtained by BLM. This tendency is more apparent for the end of the simulation period. Here, we can point out a major difference between the BLM and KNN procedures. Future precipitation and temperature are established independently when applying the BLM method, while the KNN algorithm preserves correlations that have been previously observed between these two variables. In the absence of physically-based constraints, the BLM 
procedure projects links between precipitation and temperature that differ from the actual ones. Temperature and precipitation used as input for the models and obtained by the KNN procedure are established with the strong assumption of stationarity in the physical processes. The consequence is a possible risk of masking changes in variability.

\section{IMPACT ON WATER MANAGEMENT}

In this study, simulations of the natural basin behaviour are performed using the Cequeau rainfall-runoff model of the two basins forced by transient climates provided by the KNN algorithm. The increase in mean air temperature leads to an impact on snow cover and snowmelt, i.e. a trend towards reduced winter snow storage and a shorter snowmelt season due to an earlier timing of snowmelt. Figure 6 displays the changes in hydrological regime during the period 1970-2040. Table 2 summarizes the simulations of mean seasonal flows QJFM, QAMJ, QJAS and QOND for time periods in the future. Seasons are defined to match the present-day periods of low flow and high flow. This table reports the average number of days per year $N_{<\mathrm{VCN} 10(5)}$ with daily discharge below the current annual minimum 10-day flow with a 5-year return period, VCN10(5). The value for VCN10(5) is commonly adopted as the first warning level in French drought management plans. For both basins, VCN10(5) is computed from natural observed discharges and is fixed at $8 \mathrm{~m}^{3} \mathrm{~s}^{-1}$. The two percentiles, Q95 and Q50, which are derived from inter-annual flow duration curves are also included.

"Nat" refers to natural or naturalized discharges, "Safran" to simulated discharges obtained with the Safran re-analysis and "KNN" to simulated discharges obtained with the KNN scenarios. To remove quantitative biases, changes are presented in terms of anomalies calculated for each KNN projection by difference between statistics established for the 1972-1989 period and the different periods of interest. The historic baseline differs slightly from the one chosen for the climate due to the availability of records and the 1-year spin-up period required for the models.

The main change for the two studied drainage basins is observed in spring: the peak due to snow melting is diminished and the decrease in spring total precipitation leads to a reduction in flows by about $25 \%$. It can be noted that projected changes are greater in the Ariège River basin than in the Salat River basin, clearly due to a more pronounced contribution of snowmelt within the Ariège headwaters. These changes in spring discharges accelerate the basin depletion and, combined with both warmer and drier summers, they result in a $30 \%$ reduction in summer low flows during the period 2021-2040. There is a tendency for the change in the number of days with discharge below VCN10(5) to increase consistently with decrease in QJAS. As a consequence local authorities will face more frequent and severe droughts on both basins. New strategies for water management will have to be implemented with solutions that differ from one basin to the other as no regulation infrastructure exists within the Salat River basin. By contrast, no significant change is observed in winter. Under the KNN climate warming scenarios, there is a progressive decline in Q50 and Q95. The trends displayed for the two basins share the same pattern.

After calibration of the models, simulations of reservoir management are performed using KNN climate projections. The data in Fig. 6(c) and Table 3 show that reservoir operations have a marked effect on the seasonality of changes-similar to the effect observed on present-day natural discharges - resulting in a reduction of the variability from month-to-month of the future anomalies on the natural river flow regime (Fig. 6(b)). Figure 7 shows the changes in two percentiles derived from the 
annual flow duration curves representative of low to median flows. By the 2030s, changes in median regulated discharges $\mathrm{Q}_{y} 50$ are of the same order as those found for the natural river flow regime. However, low flows represented by $\mathrm{Q}_{y} 95$ are not projected to decrease to the same extent because of the constraint imposed on minimum flows. Under the selected warming scenarios, the change in natural $\mathrm{Q}_{y} 95$ indicates that there is an increased risk of daily discharges falling to below $8 \mathrm{~m}^{3} \mathrm{~s}^{-1}$ by the 2030s (Fig. 7(a)). Nevertheless, the stored volume in the reservoirs is still sufficient to maintain $\mathrm{Q}_{y} 95$ above $8 \mathrm{~m}^{3} \mathrm{~s}^{-1}$ (Fig. 7(b)).

The effect of climate change is perceptible in the trajectory of reservoir storage (Fig. 8(a)), which is modified by both the reduced discharge in spring and the increased requirement to maintain a minimal discharge in the river during the summer. The change in the reservoir trajectory is a consequence of the change in the main drivers of storage. On average, mean temperature over France $T^{\text {France }}$ is below $15^{\circ} \mathrm{C}$ for 263 days in the $1970-1989$ period, while $T^{\text {France }}$ is below $15^{\circ} \mathrm{C}$ for 245 days in the 2021-2040 period. The reduction in the number of days when there is a benefit in carrying out releases for energy production is balanced by the increase in number of days when releases are required to guarantee minimal discharge (on average, discharge is below $8 \mathrm{~m}^{3} \mathrm{~s}^{-1}$ for 9 days in the 1971-1989 period, cf. 35 days in the 2021-2040 period). Although the total number of days when stored water is in demand is comparable at the beginning and at the end of the simulation period, their modified distribution within the year is likely to impact reservoir operations. Storage rises relatively early in the year, and is reduced slightly in the late spring. In winter, it will become less easy to release water for energy demand. This will create a loss of flexibility. Under warming climate conditions, hydropower generated in the Pyrenees will not be able to contribute to the French electric grid as in the past: the annual production of electricity will be reduced by $15-20 \%$, and reservoir flexibility during the winter demand peak periods will also be reduced.

Finally, we examine the sensitivity of the reservoir trajectory to changes in the minimal daily flow, which integrates higher downstream needs under a warmer and drier climate (Fig. 8(b)). This minimal daily flow imposed at Foix is fixed at $12 \mathrm{~m}^{3} \mathrm{~s}^{-1}$ for the whole 1970-2040 period. This increased flow is consistent with the upward trend of $20 \%$ in water needs for irrigation projected for the 2030s (Sauquet et al. 2009). Overall:

- During summer, more demands are made of reservoirs to release water for downstream needs, since natural inflow is frequently below the value of $12 \mathrm{~m}^{3} \mathrm{~s}^{-1}$ (Fig. 6(c)) observed earlier in the year.

- Drawdown starts earlier compared to results obtained using the current constraint of $8 \mathrm{~m}^{3} \mathrm{~s}^{-1}$.

- Increased daily minimum flow imposes higher storage within the year (cf. water level in the reservoirs at the end of winter). The minimum storage reached in March is less pronounced than with business-as-usual scenarios, which meet subsequent water demands (i.e. the next summer) as a first priority.

These results suggest a less contrasted trajectory, demonstrating how more severe constraints restrict the flexibility of reservoir operations, and thus point to a new compromise between energy production and other water uses.

\section{UNCERTAINTY ANALYSIS}

Investigating uncertainty in climate change impact on river flows has been an increasing concern in the last few years. Many published works compare the different 
sources of uncertainty, including future emissions of greenhouse gases, GCM structures, downscaling procedures, structure of rainfall-runoff models, etc. A multimodel approach is often adopted to quantify individual sources of uncertainty and to then examine how they propagate to runoff estimates. Rainfall-runoff models are often considered to contribute less to the overall uncertainty on river flow (e.g. Kay et al. 2009, Prudhomme and Davies 2009, Najafi et al. 2011, Teng et al. 2012), and the use of numerous climate models is strongly advised. Recent studies have shown that this hierarchy is partly dependent on the hydrological variable of interest (e.g. Ludwig et al. 2009, Chen et al. 2011, Sauquet et al. 2012). Uncertainty in GCM configuration and uncertainty stemming from hydrological model structure were considered within the IMAGINE2030 project by using multiple climate scenarios and two rainfallrunoff models, respectively. The GR4J lumped rainfall-runoff model (Perrin et al. 2003) and the Cequeau model were applied in the same conditions in calibration and simulation. A less satisfactory fit between observed and simulated discharges was obtained with the GR4J model. This is reflected in the lower NSE of 0.80 obtained for the Salat River basin (in comparison to 0.86 obtained with the Cequeau model). The results also show that under modified climate conditions the GR4J model projects more substantial decrease in summer river discharge for the two Pyrenean river basins than the Cequeau model. The GR4J model produces the largest reductions in Q50. The magnitude of change is directly dependent on the choice of the GCM and of the hydrological model. Despite the differences in the results some confidence can be placed in the fact that increased temperature will lead to reductions in the proportion of snow that contributes to runoff and to reductions in low flows in the Pyrenees.

In this study, one method was considered to downscale and bias-correct the outputs of GCMs. Uncertainty related to this step was not examined. Thus, it is not possible to draw conclusions on the relative importance of the choice of the downscaling technique. Ducharne et al. (2011) have examined climate change impacts on river discharges in northern France, extensively exploring the sources of models uncertainty. Their results show that uncertainty related to hydrological modelling and uncertainty related to downscaling could be comparable. However, it is arguable whether this conclusion applies for the Pyrenean area because of the differences in hydro-climatic conditions.

Other potential sources of uncertainty have been identified within the project IMAGINE2030. Meteorological and hydrological data used to calibrate models under current condition are not free from uncertainty. The Safran meteorological archive was based upon historical data using the available information, which is known to be sparse at high elevation. Values are highly uncertain in the mountainous areas where estimates depend on the interpolation procedure. A new re-analysis covering the main French mountainous areas is now available at 1-km resolution (Gottardi et al. 2012) and its use may contribute to quantifying the uncertainty in the data used for calibration purposes. Errors affecting observed discharge data series are linked to errors in water stage measurements and uncertainties in rating curves (Lang et al. 2010). In natural rivers, possible errors are typically around $\pm 15 \%$. Uncertainties in naturalized inflows have not been evaluated precisely, but it is evident that naturalized discharges are more uncertain than measured discharges recorded in rivers. We may suspect that the procedure leads to overestimated high flows with consequences in terms of models performance assessment. If the highest flows (above the percentile Q02) are excluded from the time series, the NSE criterion for the Cequeau model is 0.89 in calibration and 0.86 in validation, respectively. 
Model parameters are constant over time, assuming implicitly the stationarity of the hydrological processes operating in rainfall-runoff transformation. This hypothesis may not hold because land and vegetation cover will adapt in response to altered climatic conditions.

Uncertainty in parameter estimation was not investigated here. Recent works show that calibration under current climatic conditions may introduce significant biases in climate change impact studies (Coron et al. 2012, Seiller et al. 2012). In our application to the Ariège River basin, we suspect a lack of robustness because naturalized inflows are only available for a period that is too short and too dependent of climatic conditions for adequate model calibration.

The reservoir model is the result of large simplifications: (a) we simplify the hydropower facilities into one single reservoir; and (b) the technical limitations, e.g. the downstream maximum turbine flows, have not been considered. There is also uncertainty associated with equation (2) that models the marginal cost of electricity. This function results from the current equilibrium in the energy mix and from electricity consumption needs throughout the year, and has been partly validated against historical data. Under future climate, equation (2) may not hold if electricity consumption changes, or if more renewable energy is produced. The results are obtained using dynamic programming in a known future leading to optimistic predictions in terms of water allocation. Furthermore, in the light of possible future water scarcity, rules defining water allocation will certainly adapt, leading to new constraints for reservoir management in response to more frequent droughts..

\section{CONCLUSION}

In this study, we analysed the sensitivity of natural low flows and reservoir management to climate change. The Cequeau rainfall-runoff model was calibrated under present-day conditions to provide natural daily river flows under a perturbed climate consistent with IPCC AR4 monthly precipitation and temperature scenarios developed in the framework of a multi-model downscaling approach. A set of twenty 70-year daily meteorological scenarios was established representing a non-stationary, but progressively warming climate for the Garonne River basin. These projections were produced using a modified KNN algorithm calibrated against monthly air temperature trends projected by GCMs. A model was specifically developed to simulate reservoir operations. This model runs on a daily time step and solves the Bellman (1957) equation to optimize the choice between "storage today and future release for hydropower" and "release now". Under present conditions, the simplified model of hydropower reservoir management applied to the Ariège River basin reproduces fairly well the "business-as-usual" pattern of water storage and release. Under perturbed climate conditions, the results show a decline of around $15 \%$ in annual water resources for the two Pyrenean basins. The contribution of snow storage and snowmelt to runoff are both reduced, and the increase in temperature leads to more severe summer low flows. The results including reservoir management operations show a substantial effect of climate change including: (a) a decrease in energy production (due to the decrease in annual inflows), (b) an earlier filling of the reservoir and (c) an increase in water release in summer to meet summer needs. For the energy producer, full compliance with the required minimum discharge downstream from the reservoir leads to less flexibility for hydropower management during winter peak demand, whatever the future water demand scenario considered in this study case. 
This feasibility study offers an opportunity to develop and calibrate new tools for assessing the impact of climate change in France on energy production and water management. The results provide a first insight into the future hydro-electricity production for the 2030s, while including simplifying assumptions. For a more complete simulation over the Garonne River basin, we need to make additional assumptions on energy consumption, such as the development of cooling in summer, which may lead to a double peak in electricity demand. The evolution in population and the changes in agricultural practices that are likely to impact on water demand should also be examined. In the context of this feasibility study, we only explore "business-as-usual" water management. Another limitation is that reservoir operations are simulated assuming known future conditions, which, in practice, is not possible in real reservoir management. Therefore, the results from the simplified model of hydropower reservoir management may be somewhat optimistic.

Uncertainties have been partly addressed in this study. It is evident that additional work is needed to provide a more complete view of the sources of uncertainties for the future of the Garonne River basin. However, the results of the IMAGINE2030 project have convinced the French Adour-Garonne Water Agency to support other projects on climate change and to draw-up adaptation strategies for water management within the Garonne River basin using other tools ("Garonne2050" http://www.garonne2050.fr and "Adapt'eau" http://www.adapteau.fr). Developments of the models applied in IMAGINE2030 are in progress thanks to other case studies. Ongoing research in the framework of the French national project R2D2-2050 (Risk, water Resources and sustainable Development within the Durance River basin in 2050; https://r2d2-2050.cemagref.fr/) will provide an opportunity to adapt and improve this simplified model under a different climate context, to develop future scenarios for water-related sectors (energy, economic activities, agriculture) at the regional scale, to study possible options for adaptation of reservoir operations to water availability and water needs in the 2050s, and to examine in more depth the uncertainties related to climate change for large French river basins with both complex and highly-altered river flow regimes.

Acknowledgements The authors would like to thank Richard Turcotte and an anonymous reviewer for their helpful comments that improved the manuscript. Project IMAGINE2030 (contract 07-0000796) was partly supported by funding from the "Risque Décision Territoire" programme of the French Ministry for Ecology. The authors wish to thank all participants in the project, in particular Jean-Philippe Vidal (Irstea, UR HHLY), who performed. the downscaling of AR4 climate projections, Anne-Laure Jeanpierre (Irstea, UR HHLY), who implemented hydrological modelling tools under the R system (http://cran.r-project.org/), and René Samie and Anne Dupeyrat (EDF R\&D, LNHE), who carried out naturalization of the observed flows. The authors also acknowledge Météo-France for providing the Safran data set for research purposes and the French Adour-Garonne Water Agency for technical support. Dr M.S.N. Carpenter post-edited the English style.

\section{REFERENCES}

Ayadi, M. and Bargaoui, Z., 1998. Modelling of flow of the Milianne River using the CEQUEAU model. Hydrological Sciences Journal, 43 (5), 741-758.

Bellman, R., 1957. Dynamic programming. Princeton, NJ: Princeton University Press. 
Boé, J., et al., 2009. Projected changes in components of the hydrological cycle in French river basins during the 21st century. Water Resources Research, 45, W08426, doi:10.1029/2008WR007437.

Caballero, Y., et al., 2007. Hydrological sensitivity of the Adour-Garonne River basin to climate change. Water Resources Research, 43, W07448, doi:10.1029/2005WR004192.

Cavitte, J.-P. and Moor, J.-F., 2004. Dry period water management plans on Adour-Garonne basin, an example of partnership between basin authorities and the agriculture world (in French). $\mathrm{La}$ Houille Blanche, 1, 26-30.

Charbonneau, R., Fortin, J.-P., and Morin, G., 1977. The Cequeau model: description and examples of its use in problems related to water resources management. Hydrological Sciences Bulletin, 22 (1), 193-202.

Chen, J., et al., 2011. Overall uncertainty study of the hydrological impacts of climate change for a Canadian watershed. Water Resources Research, 47, W12509, doi:10.1029/2011WR010602.

Christensen, N.S. and Lettenmaier, D.P., 2007. A multimodel ensemble approach to assessment of climate change impacts on the hydrology and water resources of the Colorado River Basin. Hydrology and Earth System Sciences, 11, 1417-1434.

Christensen, N.S., et al., 2004. Effects of climate change on the hydrology and water resources of the Colorado River Basin. Climatic Change, 62, 337-363.

Coron, L., et al., 2012. Crash testing hydrological models in contrasted climate conditions: an experiment on 216 Australian catchments. Water Resources Research, doi:10.1029/2011WR011721.

Diaz-Nieto, J. and Wilby, R.L., 2005. A comparison of statistical downscaling and climate change factor methods: impacts on low flows in the River Thames, United Kingdom. Climatic Change, 69 (2-3), 245-268, doi:10.1007/s10584-005-1157-6.

Ducharne, A., et al., 2011. Evolution potentielle du régime des crues de la Seine sous changement climatique. La Houille Blanche, 1, 51-57, doi:10.1051/lhb:2011006.

Finger, D., et al., 2012. Projections of future water resources and their uncertainty in a glaciarized catchment in the Swiss Alps and the subsequent effects on hydropower production during the 21st century. Water Resources Research, 48, W02521, doi:10.1029/2011WR010733 and correction W03903, doi:10.1029/2012WR012041.

Fortin, L.G., et al., 2007. Impact des changements climatiques sur les plans de gestion des lacs SaintFrançois et Aylmer au sud du Québec (in French). Canadian Journal of Civil Engineering, 34 (8), 934-945.

Gottardi, F., et al., 2012. Statistical reanalysis of precipitation fields based on ground network data and weather patterns: Application over French mountains. Journal of Hydrology, 432-433, 154167, doi:10.1016/j.jhydrol.2012.02.014.

Hamlet, A.F. and Lettenmaier, D.P., 1999. Effects of climate change on hydrology and water resources in the Columbia River Basin. Journal of the American Water Resources Association, 35 (6), 1597-1623.

Hamlet, A.F., et al., 2010. Effects of projected climate change on energy supply and demand in the Pacific Northwest and Washington State. Climatic Change, 102, 103-128, doi:10.1007/s10584-010-9857-y.

Hendrickx, F., 2001. Impact of climate change on the hydrology of the Rhône catchment (in French). Hydroécologie Appliquée, 13, 77-100.

IPCC (Intergovernmental Panel on Climate Change), 2007. Climate change 2007: The physical science basis. In: S. Solomon, et al., eds. Contribution ofWorking Group I to the Fourth Assessment Report of the Intergovernmental Panel on Climate Change. Cambridge: Cambridge University Press.

Kay, A., et al., 2009. Comparison of uncertainty sources for climate change impacts: flood frequency in England. Climatic Change, 92 (1-2), 41-63, doi:10.1007/s10584-008-9471-4.

Klemeš, V., 1986. Operational testing of hydrological simulation models. Hydrological Sciences Journal, 31 (1), 13-24, doi:10.1080/02626668609491024.

Lall, U. and Sharma, A., 1996. A nearest neighbor bootstrap for resampling hydrologic time series. Water Resources Research, 32, 679-693.

Lang, M., et al., 2010. Extrapolation of rating curves by hydraulic modelling, with application to flood frequency analysis. Hydrological Sciences Journal, 55 (6) 201, 883-898.

Ludwig, R., et al., 2009. The role of hydrological model complexity and uncertainty in climate change impact assessment. Advances in Geosciences, 21, 63-71.

Madani, K. and Lund, J.R., 2009. Modeling California's highelevation hydropower systems in energy units. Water Resources Research, 45, W09413, doi:10.1029/2008WR007206. 
Madani, K. and Lund, J.R., 2010. Estimated impacts of climate warming on California's high-elevation hydropower. Climatic Change, 102, 521-538, doi:10.1007/s10584-009-9750-8.

Manoha, B., et al., 2008. Climate change impact on the activities of Électricité de France (in French). La Houille Blanche, 2, 55-60, doi:10.1051/lhb:2008018.

Markoff, M.S. and Cullen A.C., 2008. Impact of climate change on Pacific Northwest hydropower. Climatic Change, 87, 451-469.

Minville, M., et al., 2009. Adaptation to climate change in the management of a Canadian waterresources system exploited for hydropower. Water Resources Management, 23 (14), 29652986, doi:10.1007/s11269-009-9418-1.

Minville, M., et al., 2010. Behaviour and performance of a water resource system in Québec (Canada) under adapted operating policies in a climate change context. Water Resources Management, 24, 1333-1352.

Najafi, M.R., Moradkhani, H., and Jung, L.W., 2011. Assessing the uncertainties of hydrologic model selection in climate change impact studies. Hydrological Processes, 25 (18), 2814-2826, doi:10.1002/hyp.8043.

Nash, J.E. and Sutcliffe, J.V., 1970. River flow forecasting through conceptual models. 1. A discussion of principles. Journal of Hydrology, 10, 257-274.

NPCC (Northwest Power and Conservation Council), 2003. Genesys northwest power generation system model, version 2.7. Available from: http://nwcouncil.org/GENESYS/ [Accessed 14 December 2011].

Payne, J.T., et al., 2004. Mitigating the effects of climate change on the water resources of the Columbia River basin. Climatic Change, 62, 233-256.

Perrin, C., Michel, C., and Andréassian, V., 2003. Improvement of a parsimonious model for streamflow simulation. Journal of Hydrology, 279, 275-289, doi:10.1016/S00221694(03)00225-7.

Prudhomme, C. and Davies, H., 2009. Assessing uncertainties in climate change impact analyses on the river flow regimes in the UK. Part 2: Baseline climate. Climatic Change, 93 (1-2), 197-222, doi:10.1007/s10584-008-9461-6.

Quintana-Segui, P., et al., 2008. The SAFRAN atmospheric analysis: Description and validation. Journal of Applied Meteorology and Climatology, 47 (1), 92-107, doi:10.1175/2007JAMC1636.1.

Sauquet, E., Gottschalk, L., and Krasovskaia, I., 2008. Estimating mean monthly runoff at ungauged locations: an application to France. Hydrology Research, 39 (5-6), 403-423, doi:10.2166/nh.2008.331.

Sauquet, E., et al., 2009. Impacts anthropiques et étiages de la Garonne à l'horizon 2030. Proceedings of the "Colloque 193 SHF : Etiages, secheresses, canicules rares et leurs impacts sur les usages de l'eau”, Lyons, 7-8 October 2009.

Sauquet, E., et al., 2012. Climate and hydrological uncertainties in projections of flood and low-flows in France. Geophysical Research Abstracts, 14, EGU2012-5424.

Schaefli, B., Hingray, B., and Musy, A., 2007. Climate change and hydropower production in the Swiss Alps: quantification of potential impacts and related modelling uncertainties. Hydrology and Earth System Sciences, 11, 1191-1205.

Seiller, G., Anctil, F., and C. Perrin, P., 2012. Multimodel evaluation of twenty lumped hydrological models under contrasted climate conditions. Hydrology and Earth System Sciences, 16, 11711189, doi:10.5194/hess-16-1171-2012.

Sharif, M. and Burn, D.H., 2006. Simulating climate change scenarios using an improved k-nearest neighbor model. Journal of Hydrology, 325, 179-196.

Teng, J., et al., 2012. Estimating the relative uncertainties sourced from GCMs and hydrological models in modeling climate change impact on runoff. Journal of Hydrometeorology, 13, 122139, doi:10.1175/JHM-D-11-058.1.

Thornthwaite, C.W., 1948. An approach toward a rational classification of climate. Geographical Review, 38 (1), 55-94, doi:10.2307/210739.

Tisseuil, C., et al., 2010. Statistical downscaling of river flows. Journal of Hydrology, 385 (1-4), 279291.

Turgeon, A, 2005. Solving a stochastic reservoir management problem with multilag autocorrelated inflows. Water Resources Research, 41, W12414, doi:10.1029/2004WR003846.

USACE (US Army Corps of Engineers), 1956. Snow hydrology. Portland: North Pacific Division Corps of Engineers. 1-35, 262-268, 291-317.

USDOI (US Department of Interior), 1985. Bureau of Reclamation: Colorado River simulation system: system overview. USDOI Publication. 
Van Rheenen, N.T., et al., 2004. Potential implications of PCM climate change scenarios for California hydrology and water resources. Climatic Change, 62, 257-281.

Vicuña, S., Dracup, J.A., and Dale, L., 2011. Climate change impacts on two high-elevation hydropower systems in California. Climatic Change, 109 (Supplement 1), S151-S169, doi:10.1007/s10584-011-0301-8.

Vicuña, S., et al., 2008. Climate change impacts on high elevation hydropower generation in California's Sierra Nevada: a case study in the upper American river. Climatic Change, 28 (Supplement 1), S123-S137, doi:10.1007/s10584-007-9365-x

Vidal, J-P. and Sauquet, E., 2010. Multimodel ensemble climate projections for the Garonne River basin, France. Proceedings of the 11th international meeting on statistical climatology, Edinburgh, 12 July 2010, 167-168.

Vidal, J.-P. and Wade, S.D., 2008. A framework for developing high-resolution multi-model climate projections: 21st century scenarios for the UK. International Journal of Climatology, 28 (7), 843-858, doi:10.1002/joc.1593.

Vidal, J.-P., et al., 2010. A 50-year high-resolution atmospheric reanalysis over France with the Safran system. International Journal of Climatology, 30 (11), 1627-1644, doi:10.1002/joc.2003

Yates, D.S., et al., 2003. A technique for generating regional climate scenarios using a nearestneighbor algorithm. Water Resources Research, 39 (7), 1199, doi:10.1029/2002WR001769.

\section{FIGURES}
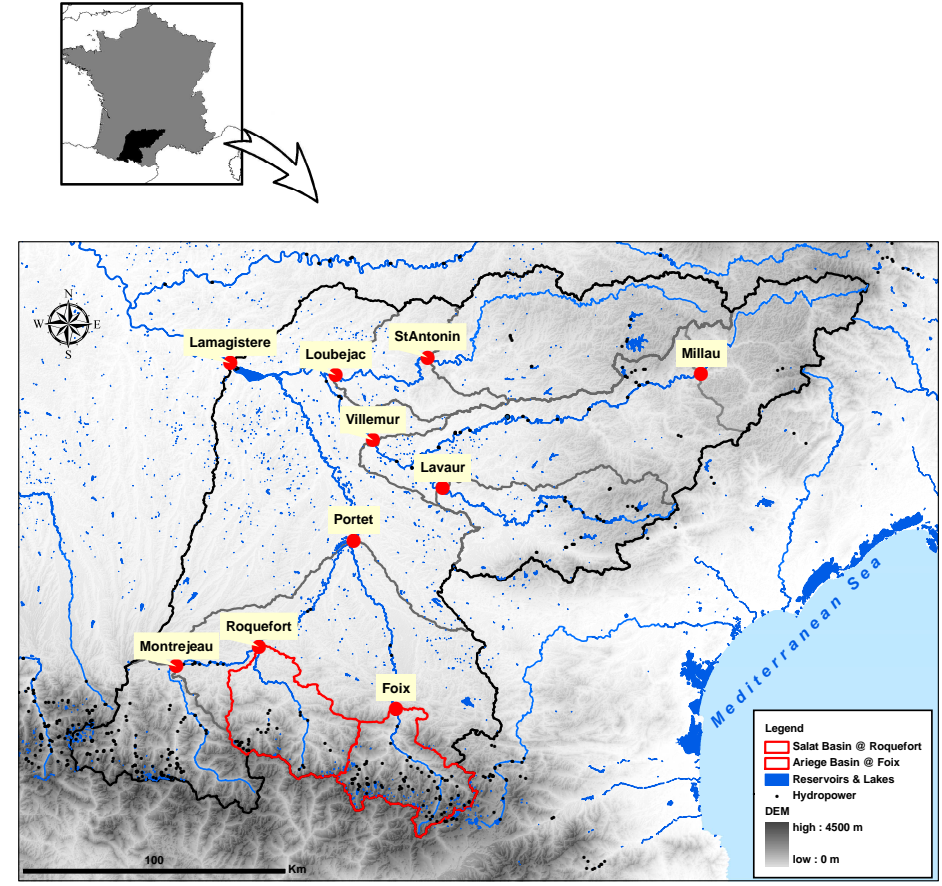
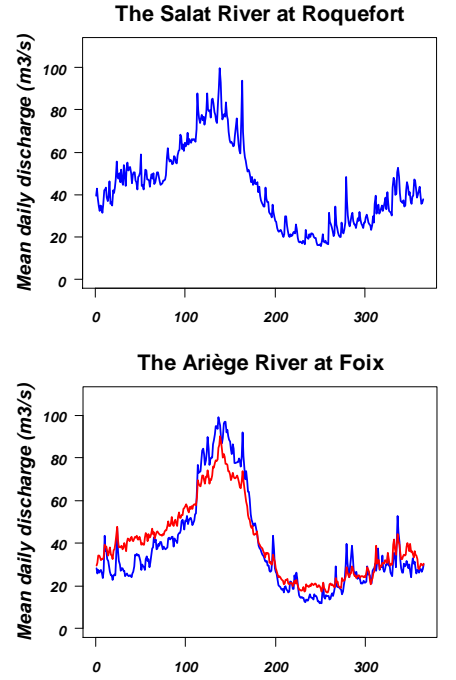

The Garonne River at Lamagistère

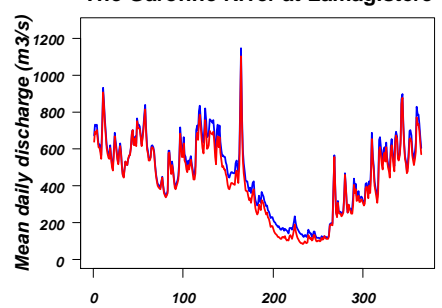

Fig. 1. Location of the two studied sub-basins (outlined in red) within the Garonne River basin upstream of Lamagistère (bottom left panel). Long-term average monthly discharge is indicated at three gauging stations under observed conditions (red) and either naturalized or natural conditions (blue) in the three panels on right. 


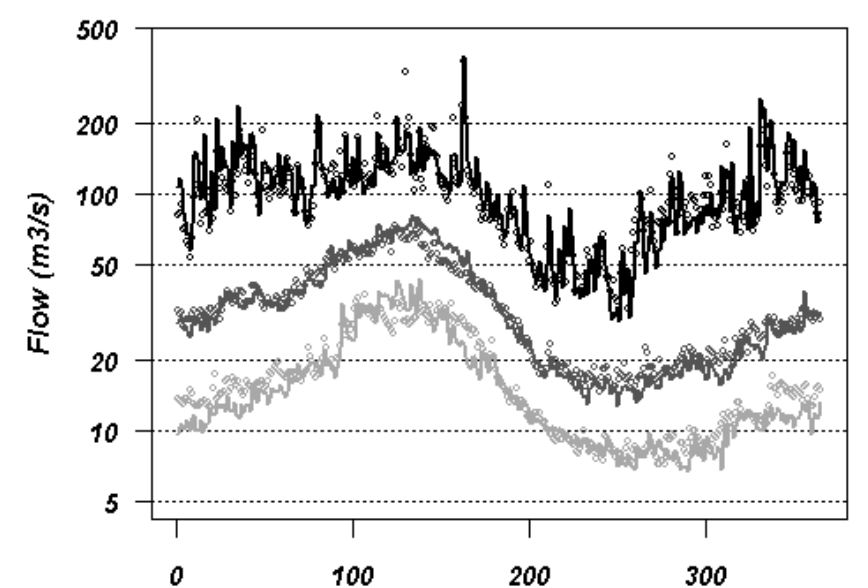

(a)

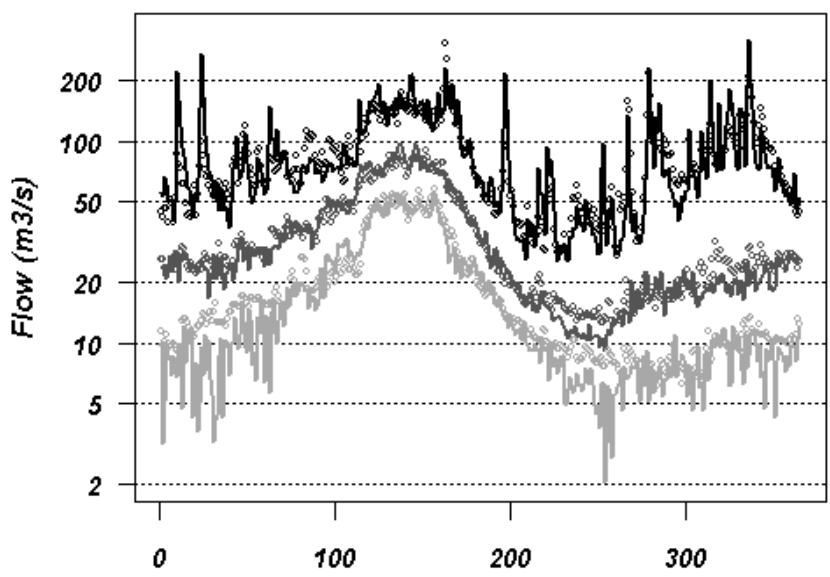

(b)

Fig. 2. Comparison of simulated $(\mathrm{O})$ and natural $(-)$ discharge statistics (black: $Q_{d} 05$, dark grey: $Q_{d} 50$, light grey: $Q_{d} 95$ ) for: (a) the Salat and (b) the Ariège river basins. The horizontal coordinate is Julian day, with Day 1 corresponding to 1 January. Control periods for the Salat and Ariège river basins are 1971-2006 and 1990-2004, respectively.

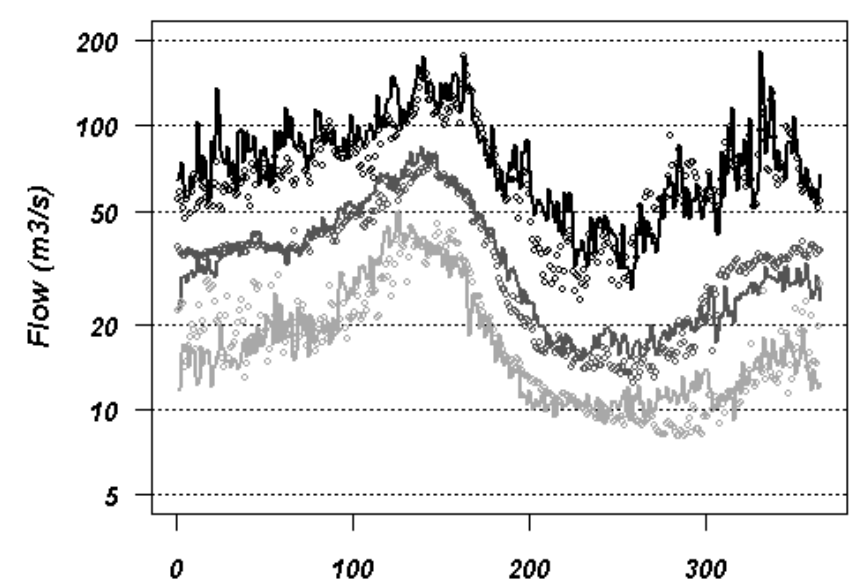

(a)

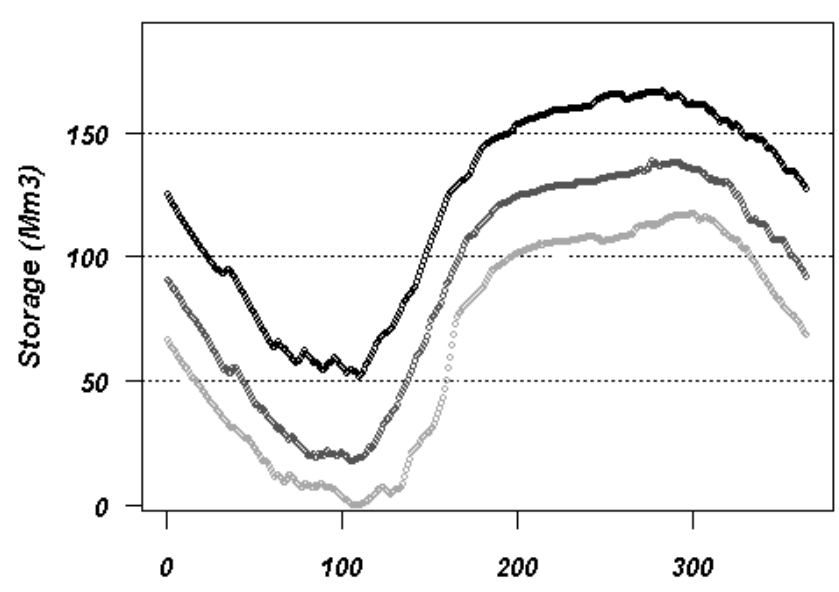

(b)

Fig. 3. (a) Comparison of simulated $(O)$ and observed $(-)$ runoff statistics for the Ariège River basin at Foix. (b) Median variation with interdecile range of daily stored water volume in reservoirs upstream from Foix. Julian day is given as the horizontal coordinate, with day one corresponding to 1 January. 


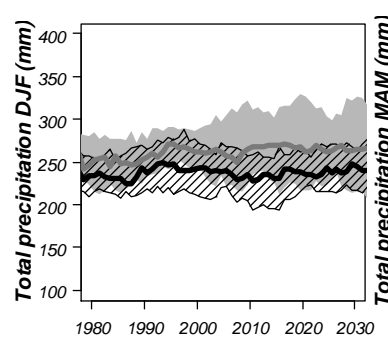

Year

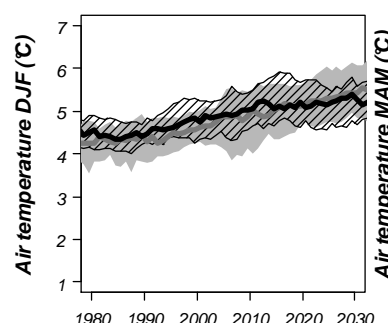

Year

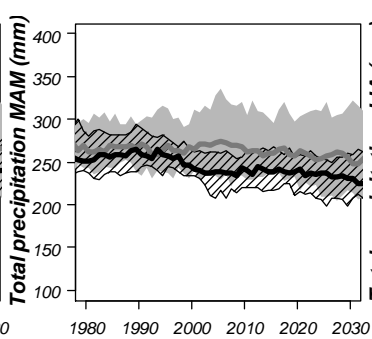

Year

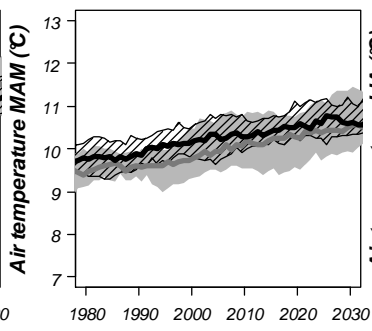

Year

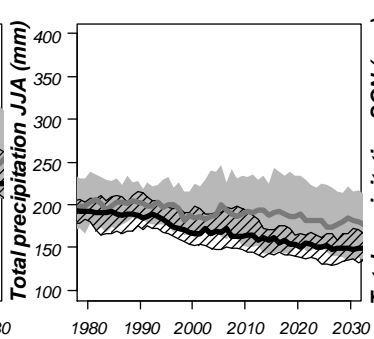

Year

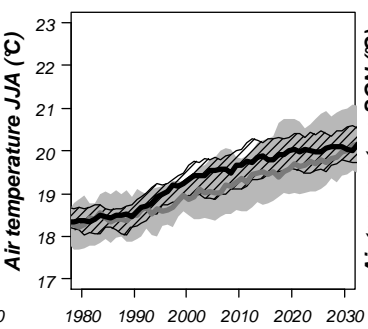

Year

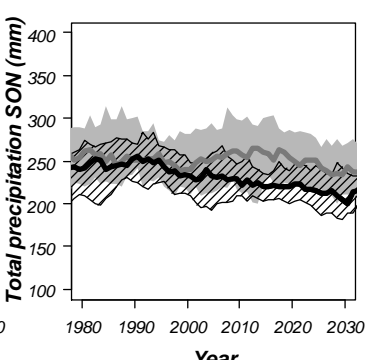

Year

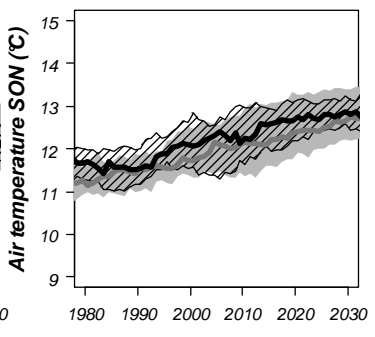

Year

Fig. 4. Median values and estimated ranges for the 10-year moving average of seasonal precipitation and air temperature. Solid lines are medians. Grey and black shading indicates the interdecile range of the 10-year moving average for the BLM and the KNN climate projections, respectively. DJF: December-January-February; MAM: March-April-May; JJA: June-July-August; SON: SeptemberOctober-November.

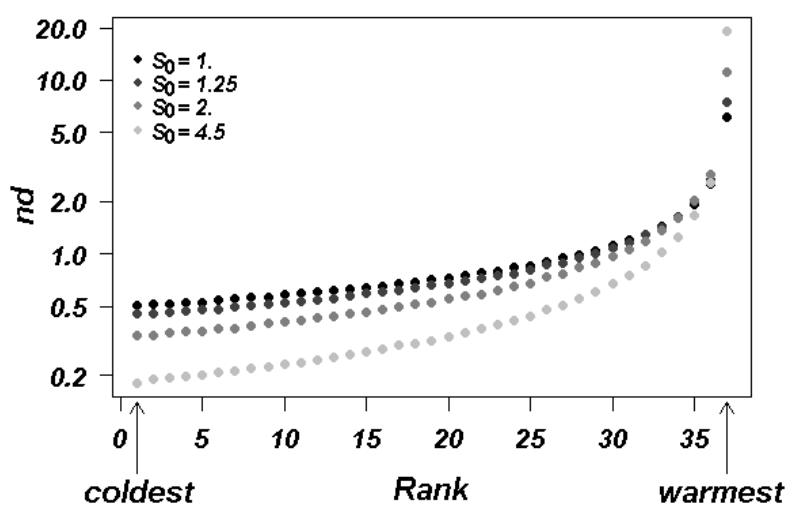

Fig. 5. Bias in $\mathrm{KNN}$ procedure expressed in terms of $\left(\mathrm{nd}_{j}, j=1, \ldots, N\right)$. 


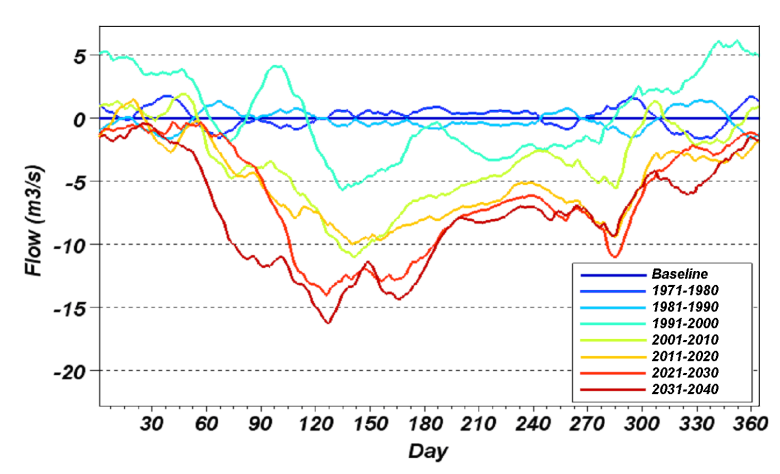

(a)

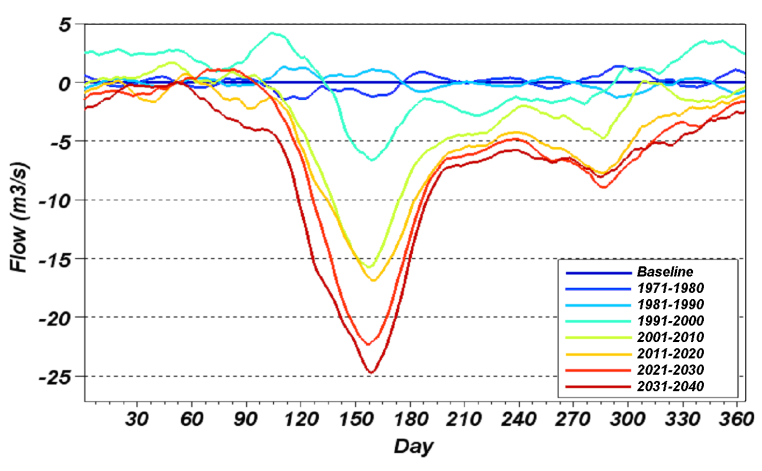

(b)

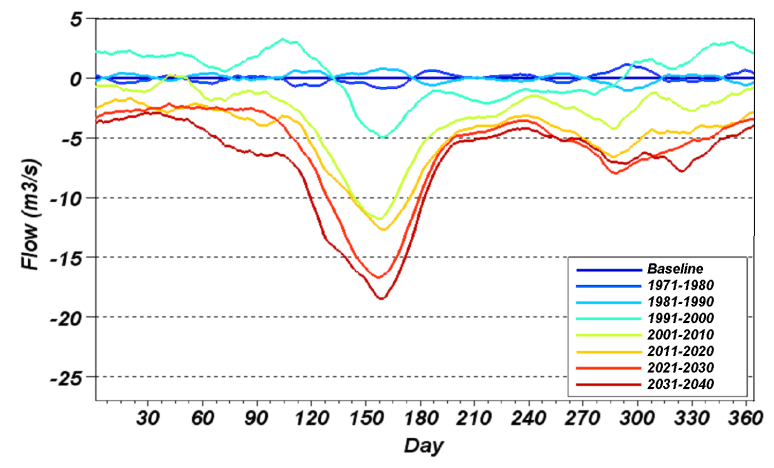

(c)

Fig. 6. Variation of average daily discharges for different 10-year time slices: (a) the Salat River basin at Roquefort; (b) the Ariège River basin at Foix; and (c) the Ariège at Foix, but including reservoir operation management.

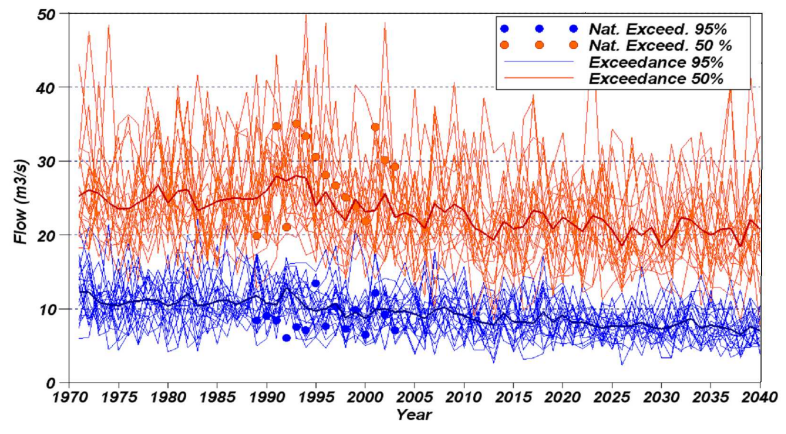

(a)

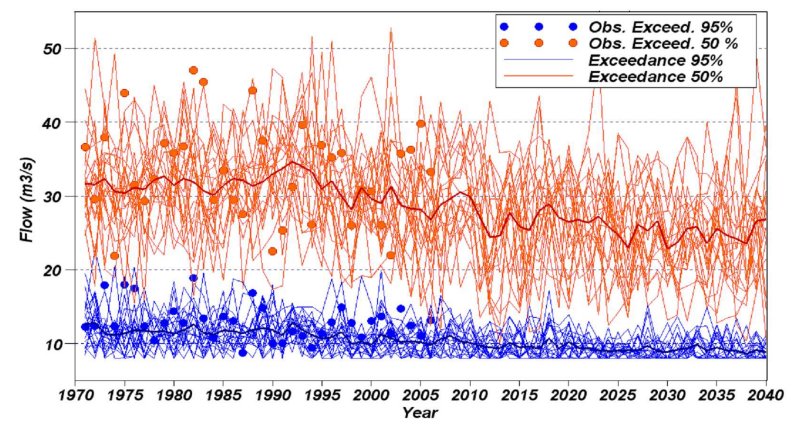

(b)

Fig. 7. Year-to-year variation in Qy95 (dark grey/blue) and Qy50 (light grey/red) for the Ariège River basin at Foix: (a) natural conditions; and (b) including reservoir operation management). Dots (•) indicate observations. The fine lines show results for a given KNN projection, the thick lines show the means of the sets of scenarios. 
Hydrological Sciences Journal, 2013

http://dx.doi.org/10.1080/02626667.2013.788790

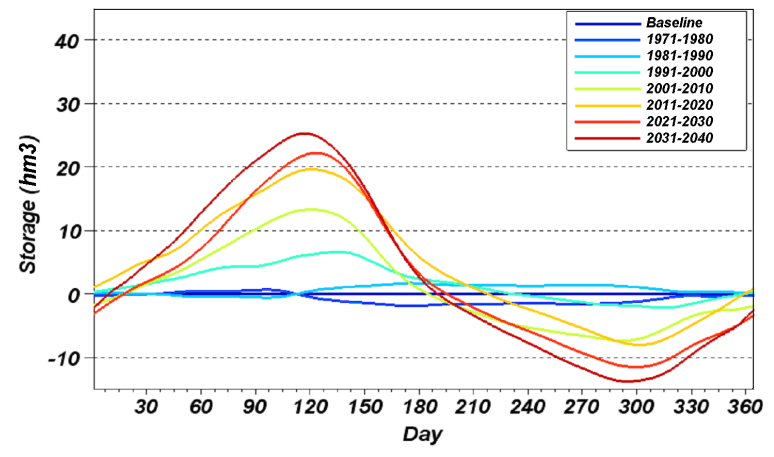

(a)

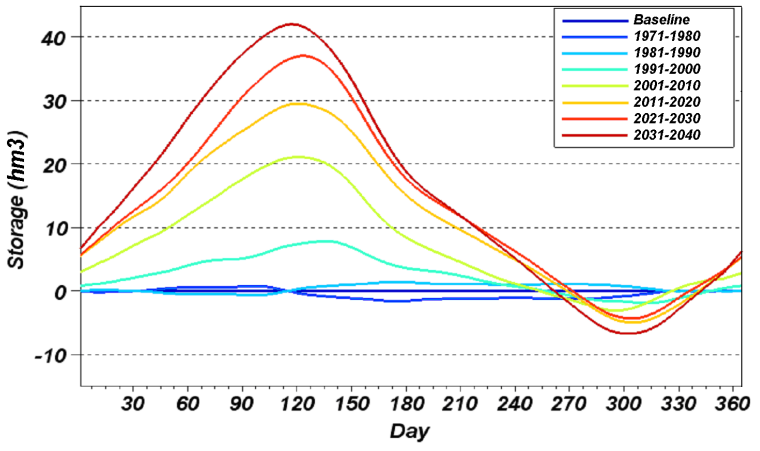

(b)

Fig. 8. 10-year average changes of daily stored water volume for different time slices for two scenarios for water management: (a) business as usual, and (b) facing increased water demand. 


\section{TABLES}

Table 1. Mean values of seasonal precipitation and temperature, with range in brackets (min; max), derived from sets of climate projections for the Garonne River basin at Lamagistère. DJF: Dec.-Feb., MAM: Mar.-May, JJA: Jun.-Aug., SON: Sep.-Nov.

\begin{tabular}{|c|c|c|c|c|c|c|c|c|c|}
\hline & \multirow[b]{2}{*}{ Period } & \multicolumn{4}{|c|}{ Precipitation (mm) } & \multicolumn{4}{|c|}{ Temperature $\left({ }^{\circ} \mathrm{C}\right)$} \\
\hline & & DJF & MAM & JJA & SON & DJF & MAM & JJA & SON \\
\hline \multirow{2}{*}{ Safran } & 1971-1989 & 269 & 280 & 199 & 226 & 4.2 & 8.9 & 18.0 & 11.4 \\
\hline & 1990-2005 & 239 & 258 & 201 & 286 & 4.3 & 10.2 & 18.9 & 11.4 \\
\hline \multirow{3}{*}{ BLM } & 1971-1989 & $\begin{array}{c}257 \\
(229 ; 283) \\
\end{array}$ & $\begin{array}{c}266 \\
(238 ; 309)\end{array}$ & $\begin{array}{c}200 \\
(171 ; 245)\end{array}$ & $\begin{array}{c}259 \\
(222 ; 315)\end{array}$ & $\begin{array}{c}4.3 \\
(3.4 ; 5.1) \\
\end{array}$ & $\begin{array}{c}9.5 \\
(8.6 ; 10.1)\end{array}$ & $\begin{array}{c}18.4 \\
(17.5 ; 19.2)\end{array}$ & $\begin{array}{c}11.3 \\
(10.5 ; 12.0)\end{array}$ \\
\hline & 1990-2005 & $\begin{array}{c}262 \\
(222 ; 293) \\
\end{array}$ & $\begin{array}{c}272 \\
(240 ; 320)\end{array}$ & $\begin{array}{c}196 \\
(166 ; 246)\end{array}$ & $\begin{array}{c}252 \\
(219 ; 280) \\
\end{array}$ & $\begin{array}{c}4.6 \\
(3.9 ; 5.3) \\
\end{array}$ & $\begin{array}{c}9.7 \\
(9.0 ; 10.8)\end{array}$ & $\begin{array}{c}18.8 \\
(17.7 ; 19.4) \\
\end{array}$ & $\begin{array}{c}11.7 \\
(11.2 ; 12.6)\end{array}$ \\
\hline & $2021-2040$ & $\begin{array}{c}266 \\
(212 ; 320) \\
\end{array}$ & $\begin{array}{c}258 \\
(192 ; 328) \\
\end{array}$ & $\begin{array}{c}179 \\
(135 ; 216)\end{array}$ & $\begin{array}{c}243 \\
(196 ; 283) \\
\end{array}$ & $\begin{array}{c}5.4 \\
(3.9 ; 6.4) \\
\end{array}$ & $\begin{array}{c}10.6 \\
(9.6 ; 11.6) \\
\end{array}$ & $\begin{array}{c}20.2 \\
(19.2 ; 21.9) \\
\end{array}$ & $\begin{array}{c}12.8 \\
(12.0 ; 14.2) \\
\end{array}$ \\
\hline \multirow{3}{*}{$\mathrm{KNN}$} & 1971-1989 & $\begin{array}{c}232 \\
(214 ; 255)\end{array}$ & $\begin{array}{c}257 \\
(231 ; 292)\end{array}$ & $\begin{array}{c}192 \\
(173 ; 217)\end{array}$ & $\begin{array}{c}242 \\
(203 ; 267)\end{array}$ & $\begin{array}{c}4.4 \\
(4.0 ; 4.9)\end{array}$ & $\begin{array}{c}9.7 \\
(9.4 ; 10.2)\end{array}$ & $\begin{array}{c}18.4 \\
(18.0 ; 18.6)\end{array}$ & $\begin{array}{c}11.5 \\
(11.1 ; 12.0)\end{array}$ \\
\hline & 1990-2005 & $\begin{array}{c}246 \\
(213 ; 286)\end{array}$ & $\begin{array}{c}246 \\
(228 ; 264)\end{array}$ & $\begin{array}{c}175 \\
(156 ; 211)\end{array}$ & $\begin{array}{c}244 \\
(206 ; 288)\end{array}$ & $\begin{array}{c}4.8 \\
(3.8 ; 5.3)\end{array}$ & $\begin{array}{c}10.1 \\
(9.4 ; 10.7)\end{array}$ & $\begin{array}{c}19.1 \\
(18.6 ; 19.4)\end{array}$ & $\begin{array}{c}12.0 \\
(10.9 ; 12.5)\end{array}$ \\
\hline & $2021-2040$ & $\begin{array}{c}239 \\
(216 ; 275)\end{array}$ & $\begin{array}{c}226 \\
(198 ; 272)\end{array}$ & $\begin{array}{c}146 \\
(131 ; 161)\end{array}$ & $\begin{array}{c}218 \\
(197 ; 253)\end{array}$ & $\begin{array}{c}5.2 \\
(4.8 ; 5.7) \\
\end{array}$ & $\begin{array}{c}10.7 \\
(10.4 ; 11.2)\end{array}$ & $\begin{array}{c}20.1 \\
(19.7 ; 20.7)\end{array}$ & $\begin{array}{c}12.7 \\
(12.0 ; 13.4)\end{array}$ \\
\hline
\end{tabular}

Table 2. Mean changes in characteristics of river flow regime, with range (min; max) in brackets for the sets of climate projections. JFM: Jan.-Mar., AMJ: Apr.-Jun., JAS: Jul.-Sep., OND: Oct.-Dec..

\begin{tabular}{|c|c|c|c|c|c|c|c|c|c|c|c|c|c|c|c|}
\hline & \multirow[b]{2}{*}{ Period } & \multicolumn{7}{|c|}{ The Salat River basin at Roquefort } & \multicolumn{7}{|c|}{ The Ariège River basin at Foix } \\
\hline & & $N_{<\mathrm{VCN} 10(5)}$ & Q95 & Q50 & QJFM & QAMJ & QJAS & QOND & $N_{<\mathrm{VCN} 10(5)}$ & Q95 & Q50 & QJFM & QAMJ & QJAS & QOND \\
\hline \multirow{2}{*}{ Nat } & 1972-1989 & 2.7 & 11.3 & 35 & 52.2 & 72.7 & 27.6 & 34.2 & & & & & & & \\
\hline & 1990-2004 & 6.1 & 9.5 & 28.7 & 42.3 & 62.0 & 20.0 & 36.3 & 15.2 & 8.4 & 27.6 & 32.5 & 70.5 & 20.2 & 28.4 \\
\hline \multirow{2}{*}{ Safran } & 1972-1989 & 3.7 & 11.2 & 34.1 & 49.2 & 67.9 & 27.6 & 33.7 & 2.5 & 10.6 & 25.2 & 29.4 & 74.9 & 25.5 & 24.8 \\
\hline & 1990-2004 & 3.3 & 10.6 & 31.4 & 44.4 & 59.3 & 22.5 & 39.1 & 4.0 & 10.4 & 28.6 & 33.6 & 67.8 & 21.1 & 30.7 \\
\hline \multirow{3}{*}{ KNN } & 1972-1989 & $\begin{array}{c}4.9 \\
(1.3 ; 8.3)\end{array}$ & $\begin{array}{c}10.6 \\
(9.6 ; 11.8)\end{array}$ & $\begin{array}{c}29.9 \\
(26.1 ; 33.1)\end{array}$ & $\begin{array}{c}45.1 \\
(41.0 ; 53.9)\end{array}$ & $\begin{array}{c}57.9 \\
(52.1 ; 64.4)\end{array}$ & $\begin{array}{c}23.6 \\
(20.5 ; 27.6)\end{array}$ & $\begin{array}{c}31.0 \\
(20.8 ; 37.8)\end{array}$ & $\begin{array}{c}9.4 \\
(4.7 ; 20.9)\end{array}$ & $\begin{array}{c}9.4 \\
(7.5 ; 10.7)\end{array}$ & $\begin{array}{c}24.2 \\
(21.4 ; 27.4)\end{array}$ & $\begin{array}{c}29.7 \\
(26.0 ; 34.8)\end{array}$ & $\begin{array}{c}63.6 \\
(57.0 ; 72.9)\end{array}$ & $\begin{array}{c}21.5 \\
(18.3 ; 26.0)\end{array}$ & $\begin{array}{c}23.5 \\
(17.0 ; 27.7)\end{array}$ \\
\hline & 1990-2004 & $\begin{array}{c}85 \\
(4.3 ; 13.3)\end{array}$ & $\begin{array}{c}9.9 \\
(8.7 ; 12.1)\end{array}$ & $\begin{array}{c}29.8 \\
(25.6 ; 34.6)\end{array}$ & $\begin{array}{c}46.0 \\
(35.8 ; 53.4)\end{array}$ & $\begin{array}{c}54.6 \\
(46.2 ; 63.0)\end{array}$ & $\begin{array}{c}20.9 \\
(18.0 ; 24.9)\end{array}$ & $\begin{array}{c}32.8 \\
(27.7 ; 42.9)\end{array}$ & $\begin{array}{c}12.6 \\
(3.3 ; 20.9)\end{array}$ & $\begin{array}{c}8.9 \\
(7.7 ; 11.7)\end{array}$ & $\begin{array}{c}24.3 \\
(20.3 ; 28.8)\end{array}$ & $\begin{array}{c}31.2 \\
(24.3 ; 35.7)\end{array}$ & $\begin{array}{c}60.5 \\
(49.6 ; 70.8)\end{array}$ & $\begin{array}{c}19.2 \\
(16.5 ; 23.7)\end{array}$ & $\begin{array}{c}24.1 \\
(19.1 ; 34.7)\end{array}$ \\
\hline & $2021-2040$ & $\begin{array}{c}23.4 \\
(14.2 ; 33.4)\end{array}$ & $\begin{array}{c}7.5 \\
(6.4 ; 8.4)\end{array}$ & $\begin{array}{c}24.5 \\
(22.7 ; 28.7)\end{array}$ & $\begin{array}{c}42.2 \\
(35.4 ; 52.8)\end{array}$ & $\begin{array}{c}45.2 \\
(37.9 ; 56.8)\end{array}$ & $\begin{array}{c}15.9 \\
(13.2 ; 20.7)\end{array}$ & $\begin{array}{c}26.0 \\
(22.2 ; 30.6)\end{array}$ & $\begin{array}{c}35.2 \\
(17.1 ; 56.7)\end{array}$ & $\begin{array}{c}6.7 \\
(5.8 ; 8.2)\end{array}$ & $\begin{array}{c}19.8 \\
(17.9 ; 22.7)\end{array}$ & $\begin{array}{c}29.1 \\
(25.5 ; 35.0)\end{array}$ & $\begin{array}{c}49.8 \\
(42.7 ; 61.0)\end{array}$ & $\begin{array}{c}14.7 \\
(12.5 ; 17.6)\end{array}$ & $\begin{array}{c}18.2 \\
(14.9 ; 21.6)\end{array}$ \\
\hline
\end{tabular}

Table 3. Mean changes in characteristics of river flow regime for the Ariège River basin at Foix, but including reservoir operation management. For explanation, see Table 2.

\begin{tabular}{|c|c|c|c|c|c|c|c|}
\hline & Period & Q95 & Q50 & QJFM & QAMJ & QJAS & QOND \\
\hline \multirow{2}{*}{ Obs } & 1972-1989 & 12.5 & 33.6 & 40.7 & 67.1 & 25.5 & 29.7 \\
\hline & 1990-2004 & 11.5 & 30.6 & 41.1 & 57.6 & 20.4 & 31.4 \\
\hline \multirow{2}{*}{ Safran } & 1972-1989 & 11.6 & 33.6 & 37.8 & 59.0 & 21.5 & 31.3 \\
\hline & 1990-2004 & 11.3 & 35.1 & 41.4 & 56.9 & 18.9 & 35.9 \\
\hline \multirow{3}{*}{ KNN } & 1972-1989 & $\begin{array}{c}10.6 \\
(9.7 ; 11.7)\end{array}$ & $\begin{array}{c}31.5 \\
(28.2 ; 35.0)\end{array}$ & $\begin{array}{c}37.8 \\
(33.9 ; 42.3)\end{array}$ & $\begin{array}{c}52.8 \\
(47.0 ; 60.0)\end{array}$ & $\begin{array}{c}19.1 \\
(16.6 ; 22.7)\end{array}$ & $\begin{array}{c}28.8 \\
(22.9 ; 32.7)\end{array}$ \\
\hline & 1990-2005 & $\begin{array}{c}10.1 \\
(9 ; 12.2)\end{array}$ & $\begin{array}{c}30.7 \\
(24.4 ; 36.2) \\
\end{array}$ & $\begin{array}{c}38.4 \\
(30.5 ; 44.4) \\
\end{array}$ & $\begin{array}{c}50.3 \\
(41.7 ; 60.7) \\
\end{array}$ & $\begin{array}{c}17.3 \\
(15.2 ; 21.0 \\
\end{array}$ & $\begin{array}{c}29.1 \\
(24.4 ; 39.1) \\
\end{array}$ \\
\hline & $2021-2040$ & $\begin{array}{c}8.3 \\
(8 ; 9.15) \\
\end{array}$ & $\begin{array}{c}24.6 \\
(21.2 ; 29.7) \\
\end{array}$ & $\begin{array}{c}34.4 \\
(30.3 ; 41.0) \\
\end{array}$ & $\begin{array}{c}41.2 \\
(35.4 ; 50.4) \\
\end{array}$ & $\begin{array}{c}14.0 \\
(12.4 ; 16.2) \\
\end{array}$ & $\begin{array}{c}22.9 \\
(19.1 ; 27.1) \\
\end{array}$ \\
\hline
\end{tabular}

